\title{
Expected Benefits of Implementing Global Accounting Standards by Nigerian Business Entities
}

\author{
Nyor, Terzungwe ${ }^{1}$ \\ ${ }^{1}$ Department of Economics and Management Sciences, Nigerian Defence Academy, Kaduna, Nigeria \\ Correspondence: Nyor, Terzungwe, Department of Economics and Management Sciences, Nigerian Defence \\ Academy, PMB 2109, Kaduna, Nigeria. Tel: 234-80-5442-3022. E-mail: loterz@yahoo.com
}

Received: February 24, 2012

Accepted: March 26, 2012

Published: August 1, 2012

doi:10.5539/ijbm.v7n15p98

URL: http://dx.doi.org/10.5539/ijbm.v7n15p98

\begin{abstract}
As Nigeria converges to IFRS in 2012, this study draws from empirical works on the implementation of the standards to highlight the benefits that would be derived by Nigerian firms from implementing a global accounting standard. Using a descriptive research approach, the study documents the benefits of converging to IFRS as being easy comparison of financial statements leading to global financial harmonization, access to capital, enhanced cross-border listing, increased transparency, enhanced competitiveness and the elimination of the need for reconciliation of information reported under different national standards among others. The study recommends the adoption of the International Financial Reporting Standards by Nigerian companies in order for them to take advantage of globalization effects.
\end{abstract}

Keywords: benefits, implementation, globalization, accounting standards, financial statements

\section{Introduction}

There is a rapid worldwide economic and political integration that is facilitating cross border capital flows. An example is the collapse of communism in Europe and the wake of democratization across Arab countries. The world today has embraced democracy and capitalism. Many barriers to global trade have been eroded and world economies have become increasingly linked together. Hence, there is need to develop a truly global language of business that is common, in order to communicates financial results of enterprises to various users. Globalization of businesses has brought to fore the need for a financial statement that is comparable in every sense, not only in the format of disclosure but in the treatment of accounting issues.

The International Financial Reporting Standards (IFRS) issued by the International Accounting Standard Board (IASB) is a single set of high quality accounting standards that protect investors and ensures efficient and effective capital formation and allocation in today's global business world. It is considered to be a gift to global investors as it enables comparison of financial numbers of corporations no matter their location. IFRS are principle based set of accounting standards in the sense that, they establish broad rules as well as dictate specific treatment (Wikipedia, 2011). Convergence to IFRS has gained momentum in recent years all over the world as capital markets have increasingly become global in nature. Tearney and Dodd (2011) describes IFRS as accounting for international transactions, comparison of accounting principles in different countries, harmonization of accounting standards worldwide and accounting information for the management and control of global business operation.; while Riahi (2000) refers to it as world accounting which directs the formulation and study of a universally accepted set of accounting principles.

Nigeria is beginning a staged adoption of the International Financial Reporting Standards (IFRS) in January, 2012. The Government explained the need to adopt a global accounting standard by saying that Nigerian companies have raised capital from international stock markets and have established their presence in other countries of the world, while many Nigerians hold securities of non Nigerian issuers. Moreover, world economies are interconnected and nations are desirous of moving forward by freeing themselves from the limits of the present system of financial reporting. This collaborate the evidence by Ball (2004) that companies, especially firms competing in global markets, may face competitive disadvantage from an inefficient financial reporting models that have no global acceptance. Thus, harmonization of financial reporting has led to 
comparable accounting and financial information across the globe and continues to support and advance business itself.

As Nigeria converges to global accounting standard in 2012, would that convert to economic and financial benefits to Nigerian firms looking at the experiences of countries that have already implemented IFRS? This is the question that this study seeks to find answers to, with a view to determining whether the adoption which has cost effects and is still surrounded by controversies over acceptance base, is worth while. The study gives an overview of IFRS in the following section, then, states its methodology, and documents empirical evidence on benefits of implementing global accounting standards. The study concludes and recommends actions to be taken by Nigerian firms.

\section{Overview of IFRS}

International Financial Reporting Standards (IFRS) are a set of accounting standards developed by the International Accounting Standard Board (IASB). The IASB succeeded IASC (International Accounting Standards Committee) in 2001, and within a decade of its operation, the IFRS has become the global standard for the preparation of financial statements by public quoted companies (Wharton School, 2007). The IASB is an independent accounting standard setting body. With 15 members from nine countries, it has its base in London. It is funded by contributions and donations from international organizations and professional bodies throughout the world.

IFRS is composed of framework (norms), standards and interpretations. IASB is guided by Conceptual Framework in the development of future standards and review of existing IFRSs. The Board adopted the Framework in April 2001. The framework sets out concepts that underlie the preparation and presentation of Financial Statements for external users. It also deals with the objectives of financial reporting, the qualitative characteristics of useful financial information, definitions, recognition and measurement of the elements from which financial statements are constructed and the concept of capital and capital maintenance. Where there is conflict between the conceptual framework and any IFRS, the requirements of the takes precedence over those of the conceptual framework (IASB, 2011).

IFRS are principle based set of standards (based on sound, clearly stated principles) as opposed to rules-based like the US Generally Accepted Accounting Principles (GAAP). They establish broad rules and dictate specific treatment of items. However, SEC (2001) believes that it allowed for multiple alternatives treatments of one transaction and thus limits the comparability and harmonization of financial statements. Each standard controls certain bookkeeping entry, valuation and requirements for presentation of information. The standards comprise of some IAS issued before 2001 and IFRS issued after 2001. IFRS require more disclosure in the financial statements that the former IAS (Ankarath 2010). Appendix I contains the list of the IFRS. Interpretations issued after 2001by the International Financial Reporting Interpretations Committee (IFRIC) and those issued by the former Standing Interpretations Committee (SIC) before 2001 complete the standards.

Some differences in presentation of financial information exist between Nigerian GAAP and IFRS. The Value Added statement and Five Year Financial Summary is absent in IFRS, while Statement of other Comprehensive Income in IFRS is not in the Nigerian GAAP. The Balance Sheet and Profit and Loss Account in the Nigerian GAAP is known as Statement of Financial Position and Income Statement respectively in IFRS. Statement of Cash Flows, Accounting Policies and Explanatory Notes are however, similar to both. Only financial statements that comply fully with IFRS can be referred to as IFRS financial statements.

\section{Methodology}

This study is exploratory in nature (Wirtanen, 2009). The reason is because, Nigeria is yet to implement IFRS. The stage adoption of the global accounting standard commences January 2012 by publicly quoted companies (Business World, 2010). Other Public Interest Entities (PIES) are to converge to IFRS by 1 January, 2013 and small and medium size entities will converge by 1 January, 2014. Since hardly anything is known about the object, the study only documents the experiences of other countries that have so far implemented IFRS. Thus, the choice of descriptive research design to explain the benefits of adopting global accounting standards by Nigerian firms is informed by the fact that, this study aims at recording in the form of a written report, that which has been perceived. This is with a view to helping Nigerian firms in making cost-benefit analysis as the implementation of the global accounting standard is not without cost effects.

\section{Benefits of Implementing IFRS}

Some countries that have so far implemented IFRS have good stories to tell about it. In Germany, German companies were exposed to burdensome, cost intensive dual accounting by the German GAAP. They were also 
not allowed to be quoted on the New York Sock Exchange because of marked differences with the US GAAP. The adoption of IFRS by Germany has resolved all that and their firms can now enjoy cross border listing on the New York Stock market. Zambia's financial sector now benefits from IFRS implementation in terms of high quality reports as well as cross-border comparability of financial performance among banks (Nwape, 2010). The implementation has brought to India, the benefits of greater comparability of financial information and willingness on the part of investors to invest in Indian firms, lower cost of capital and more efficient allocation of capital (UNCTAD, 2008).

Russian Task Force identified benefits of converging to IFRS by companies as improved management information for decision making, better access to capital, including from foreign sources, reduced cost of capital, ease of using one consistent reporting standard in subsidiaries from different countries, facilitated mergers and acquisitions, enhanced competitiveness. The task force equally documented benefits to investors such as better information for decision making, more confidence in the information presented; better understanding of risk and return, companies can be compared to a peer group of companies. They equally argued that IFRS will strengthen the Russian capital market, by making it more effective, providing access to the global capital markets, promotion of cross-border investment ((Russian Corporate Governance Roundtable, 2004).

Wong (2004) provides evidence that investors will be more willing to diversify their investments across borders if they are able to rely on financial information that is based on a similar set of standards. Thus, adoption of international standards will ultimately lead to greater economic expansion. Dunne et al (2008) documents the benefits arising from the adoption of international standards to include: access to capital; enhanced cross-border listing; better investment opportunities; increased transparency; comparability and the opportunity to review existing policies. They argue that argue that better transparency and disclosure help external actors to monitor the actions of managers, reduces information asymmetry and the risk of expropriation, thus, lowering the risk premium and reducing the cost of capital.

Firms tend to display higher leverage measures, such as long-term liabilities to capital employed, total liabilities to shareholders' funds and interest cover under the use of IFRS. IFRS produces higher quality of financial reporting, enhances the credibility of firm financial statements, and in turn provides lenders with more certainty and information about the ability of firms to timely meet their financial obligations, thus, leading to better borrowing terms.(George, 2010).

It is expected that the implementation of the global accounting standards would yield benefits all over the world, not only for companies implementing it but even for investors, policy makers, regulatory bodies, as well as stakeholders. According to Angie, (2004), implementation of IFRS will bring about greater comparability. Financial statements prepared using the same standards can be compared more accurately. This is important especially when comparing companies located in different countries, since they might be using different standards to prepare their statements. This increase in comparability would help investors to better determine where their investment should go.

In the same vein, Blanchette and Desfleurs, (2011) opined that not only will the adoption of IFRS improve the clarity and comparability of financial information globally, it will also prove cost effective by eliminating the need for reconciliations of information reported under different national standards. Financial statements based on a single set of standards should allow better comparisons as long as the standards are understandable, do not permit too many choices and uncertain estimates, and are applied uniformly. It would be less costly for investors to compare firms across markets and countries if IFRS is applied uniformly. Furthermore, companies with subsidiaries in countries that require or permit the use of IFRS may be able to use one accounting language company-wide. Companies may also benefit by using IFRS if they wish to raise capital abroad.

Markets are as well becoming integrated for private companies, both large and small. Hence, the benefits of global standards are not limited to public companies alone. More private companies are seeking to do across border business and obtain financing from foreign sources. Reduced complexity, increased comparability, greater transparency, and improved efficiency are all potential benefits of IFRS for private firms. (Delloitte, 2009)

\section{Conclusion and Recommendation}

From the evidence documented above, the study concludes that the implementation of IFRS has obvious benefits. Some of the benefits are: easy comparison of financial statements leading to global financial harmonization, cost efficiency and cost reduction, access to capital, enhanced cross-border listing, better investment opportunities, increased transparency, opportunity to review existing policies, better borrowing terms, flexibility, reduced cost of capital, access to global capital markets, enhanced competitiveness and the elimination of the need for 
reconciliation of information reported under different national standards. The study recommends the adoption of the International Financial Reporting Standards by Nigerian companies in order for them to take advantage of globalization effects.

\section{References}

American Institute of Certified Public Accountants. (2008). Questions and answers. Retrieved September 29, 2011 from http://www.ifrs.com

Angie M. (2011). International financial reporting standards - advantages and disadvantages. Retrieved September 29, 2011 from http://www.chronicle.com

Ankarath N., Mehta K. J., Ghosh P. T., \& Alkafaji A. Y. (2010). Understanding fundamentals international financial reporting standards (IFRS). Retrieved October 2, 2011 from http://www.wiley.com/accounting

Ball, R. (2004). From a 'stakeholder' towards a 'stakeholder value'. The Economics and Politics of Accounting: International Perspectives on Research, Trends, Policy and Practice. Oxford University Press

Blanchette M., \& Desfleurs A. (2011). Critical perspectives on the implementation of IFRS in Canada. Journal of Global Business Administration (JGBA), 3(1). Retrieved from http://www.google.com

Business World. (2010). IFRS- Matters arising in Nigeria. Published 7 September, 2010.

Cuijpers, R., \& Buijnik Willem. (2005). Voluntary adoption of non-local GAAP in the European Union: a study of determinants and consequences. European Accounting Review, 14(3), 487-524.

Delloitte. (2009). Internationa Financial Reporting Standards: What it means for Private companies reporting. Retrieved September 29, 2011 from http://www.deloitte.com/us/privateenterprise

Dunne T., Finningham G., Hanna G., Power D., Fifield S., \& Fox A et al. (2008). The implementation of IFRS in the UK, Italy, and Ireland. Edinburgh: Institute of Chartered Accountants of Scotland. Retrieved September 29, 2011 from http://www.icas.org.uk/research

George, I. (2010). IFRS adoption and financial statement effects: UK case. Institutional Research Journal of Finance and Economics. Retrieved from http://www.eurojournals.com/finance.htm

IASB. (2011). IASB work plan. Retrieved September 29, 2011 from http://www.iasb.org/aboutus

Nwape, K. A. (2010). Lessons learned from implementing IFRS: A regulators perspective. Bank of Zambia, July, 2010.

Riahi B.A. (2000). Accounting Theory ( $4^{\text {th }}$ Edition). Padstow, Cornwall: Business Press.

Russian Corporate Governance Roundtable. (2004). Implementing international financial reporting standards (IFRS) in Russia. Retrieved October 2, 2011 from http://www.google.com

Simon G. (2008). Managing the transition to international financial reporting standards. Retieved September 29, 2011 from http:// www.oracle.com

Teaney, K., \& Dodd, C. (2011). Coming to Terms with International Accounting Standards. Houston: Gulf Publishing.

UNCTAD. (2008). Practical implementation of international financial reporting standards: lessons from Europe. Retrieved October $\quad 2, \quad 2011$ from http://.auditcommission.gov.uk/health/audit/financialmgmt/ifrs/pages/ifrsbriefingpaper.aspx

Wharton School. (2007). Do international financial reporting standards live up to their promise? Retrieved from $\mathrm{http}$ :/www.knowledge.wharton.upenn.edu/article

Wikipedia. (2011). Retrieved September 29, 2011 from http://www.wikipedia.com/ias

Wirtanen, J. (2009). The Influences of IFRS Implementation on Business Management in Finish Born Globals. Accounting Masters Thesis. Department of Accounting and Finance, Helsingin Kauppakorkeakoulu. Retrieved from htt:hsepubl.lib.hse.fi/EN/ethesis/pdf/12066/hsethesis 12066.pdf

Wong P. (2004). Challenges and successes in implementing international standards: achieving convergence to IFRS and ISAS. International Federation of Accountants. Retrieved October 1, 2011 from http://www.ifac.org 


\section{Appendix I: LIST OF IFRS}

\section{IFRS Issued before 2001}

IAS 1: Presentation of Financial Statements

IAS 2: Inventories

IAS 7: Statement of Cash Flows

IAS 8: Accounting Policies, Changes in Accounting Estimates and Errors

IAS 10: Events after the Reporting Period

IAS 11: Construction Contracts

IAS 12: Income Taxes

IAS 16: Property, Plant and Equipment

IAS 17: Leases

IAS 18: Revenue

IAS 19: Employment Benefits

IAS 20: Accounting for Government Grants

IAS 21: Te Effects of Changes in Foreign Exchange Rates

IAS 23: Borrowing Costs

IAS 24: Related Party Disclosures

IAS 26: Accounting and Reporting by Retirement Benefit Plans

IAS 27: Consolidated and Separate Financial Statements

IAS 28: Investment in Associates

IAS 29: Financial Reporting in Hyperinflationary Economies

IAS 31: Interest in Joint Ventures

IAS 32: Financial Instruments: Presentation

IAS 33: Earnings per Share

IAS 34 Interim Financial Reporting

IAS 36: Impairment of Assets

IAS 37: Provisions, Contingent Liabilities and Contingent Assets

IAS 38: Intangible Assets

IAS 39 Financial Instruments: Recognition and Measurement

IAS 40: Investment Property

IAS 41: Agriculture 


\section{IFRS Issued after 2001}

IFRS 1: First-time Adoption of International Financial Reporting Standards

IFRS 2: Share-based Payment

IFRS 3: Business Combinations

IFRS 4: Insurance Contracts

IFRS 5: Non-current Assets Held for Sale and Discontinued Operations

IFRS 6: Exploration for and Evaluation of Mineral Assets

IFRS 7: Financial Instruments: Disclosures

IFRS 8: Operating Segments

IFRS 9: Financial Instruments

\section{APPENDIX II: LIST OF BENEFITS OF IMPLEMENTING IFRS AND THEIR RELATED REFERENCES}

\begin{abstract}
Benefits of Implementing IFRS
In Germany, German companies were exposed to burdensome, cost intensive dual accounting by the German GAAP. They were also not allowed to be quoted on the New York Sock Exchange because of marked differences with the US GAAP. The adoption of IFRS by Germany has resolved all that and their firms can now enjoy cross border listing on the New York Stock market.

In India, the implementation has brought the benefits of greater comparability of financial information and willingness on the part of investors to invest in Indian firms, lower cost of capital and more efficient allocation of capital.
\end{abstract}

Zambia's financial sector now benefits from IFRS implementation in terms of high quality reports as well as cross-border comparability of financial performance among banks.

\author{
Related References
}

UNCTAD, (2008). Practical implementation of international financial reporting standards: lessons from Europe. Retrieved October 2, 2011 from http://.auditcommission.gov.uk

\begin{abstract}
Russian Task Force identified benefits of converging to IFRS by companies as improved management information for decision making, better access to capital, including from foreign sources, reduced cost of capital, ease of using one

Russian Corporate Governance Roundtable (2004). Implementing international financial reporting standards (IFRS) in Russia. Retrieved October 2, 2011 from http://www.google.com.
\end{abstract} consistent reporting standard in subsidiaries from different countries, facilitated mergers and acquisitions, enhanced competitiveness.

Benefits to investors include better information for decision making, more confidence in the information presented; better understanding of risk and return, companies can be compared to a peer group of companies.

In Russia, IFRS will strengthen the Russian capital market, by making it more effective, providing access to the global capital markets, promotion of cross-border investment.
Nwape, K. A. (2010) Lessons learned from implementing IFRS: A regulators perspective. Bank of Zambia, July, 2010. 
Investors will be more willing to diversify their investments across borders if they are able to rely on financial information that is based on a similar set of standards. Thus, adoption of international standards will ultimately lead to greater economic expansion.

Access to capital; enhanced cross-border listing; better investment opportunities; increased transparency; comparability and the opportunity to review existing policies. Better transparency and disclosure help external actors to monitor the actions of managers, reduces information asymmetry and the risk of expropriation, thus, lowering the risk premium and reducing the cost of capital.

Firms tend to display higher leverage measures, such as long-term liabilities to capital employed, total liabilities to shareholders' funds and interest cover under the use of IFRS. IFRS produces higher quality of financial reporting, enhances the credibility of firm financial statements, and in turn provides lenders with more certainty and information about the ability of firms to timely meet their financial obligations, thus, leading to better borrowing terms.

\begin{abstract}
Adoption of IFRS will not only improve the clarity and comparability of financial information globally, it will also prove cost effective by eliminating the need for reconciliations of information reported under different national standards. Financial statements based on a single set of standards should allow better comparisons as long as the standards are understandable, do not permit too many choices and uncertain estimates, and are applied uniformly. It would be less costly for investors to compare firms across markets and countries if IFRS is applied uniformly. Companies with subsidiaries in countries that require or permit the use of IFRS may be able to use one accounting language company-wide. Companies may also benefit by using IFRS if they wish to raise capital abroad.
\end{abstract}

\footnotetext{
Markets are as well becoming integrated for private companies, both large and small. Hence, the benefits of global standards are not limited to public companies alone. More private companies are seeking to do across border business and obtain financing from foreign sources. Reduced complexity, increased comparability, greater transparency, and improved efficiency are all potential benefits of IFRS for private firms.
}

Wong P. (2004). Challenges and successes in implementing international standards: achieving

convergence to IFRS and ISAS. International Federation of Accountants. Retrieved October 1, 2011 from http://www.ifac.org

Dunne T., Finningham G., Hanna G., Power D., Fifield S., \& Fox A. et al. (2008). The implementation of IFRS in the UK, Italy, and Ireland. Edinburgh: Institute of Chartered Accountants of

Scotland. Retrieved September 29, 2011 from http://www.icas.org.uk/research.

George, I. (2010). IFRS adoption and financial statement effects: UK case. Institutional Research Journal of Finance and Economics. Retrieved from

http://www.eurojournals.com/finance.htm

Blanchette M. \& Desfleurs A. (2011). Critical perspectives on the implementation of IFRS in Canada. Journal of Global Business Administration 3 (1). Retrieved from http://www.google.com

Delloitte (2009) Internationa Financial Reporting Standards: What it means for Private companies reporting. Retrieved September 29, 2011 from http:/www.deloitte.com/us/privateenterprise 